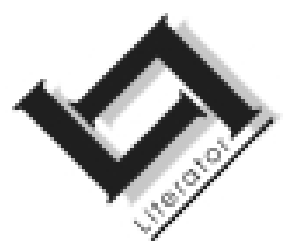

\title{
Stagnering en transformering: die rol van die nar in Paljas
}

Adéle Nel

Skool vir Tale

Vaaldriehoekkampus

Potchefstroomse Universiteit vir $\mathrm{CHO}$

VANDERBIJLPARK

E-pos: afnan@puknet.puk.ac.za

Abstract

Stagnation and transformation: The role of the clown in Paljas

This article focuses on the central problem in the film Paljas, and the role of the clown in the process of transformation that is embedded in the story. The stagnation in interpersonal relationships and the accompanying problem of identity on a personal and social level constitute the problem underlying the narrative. The youngest child refuses to speak and dysfunctional family relationships and marital problems are evident. These problems can mainly be ascribed to the spatial isolation in which the characters find themselves. Attention is therefore paid to the way in which space functions in this film. The arrival of an absconded circus clown effects transformation and healing - especially by means of his picaresque performances and the notion of play. Subsequently this article concentrates on the characteristics of game/playing as a cultural activity and on its liberating value. The clown also has definite Biblical connotations as far as the aspects of betrayal and redemption are concerned. The process of transformation as depicted in this film is completed when the child starts speaking again, dysfunctional family relationships are restored and the family is reinstated in the community because of their restored social status.

\section{Opsomming}

Stagnering en transformering: die rol van die nar in Paljas

Hierdie artikel fokus op die sentrale problematiek in die film Paljas, en die rol wat die nar speel in die transformeringsproses wat plaasvind. Die sentrale problematiek onderliggend aan die verhaal is 'n stagnering in interpersoonlike verhoudings en 'n gepaardgaande identiteitsproblematiek op persoonlike en sosiale vlak. Die jongste kind weier om te praat en 
disfunksionele gesinsverhoudings en huweliksprobleme is duidelik. Die problematiek in die verhaal kan onder andere toegeskryf word aan die ruimtelike isolasie waarin die karakters hulle bevind. Daar word dus aandag geskenk aan die wyse waarop ruimte in die film funksioneer. Transformasie en heling vind plaas deur die tussenkoms van 'n verloopte sirkusnar. Dit geskied veral deur die nar se pikareske vertonings en die nosie van spel. Daar word gevolglik ook in die artikel gefokus op die onderskeidende kenmerke van spel as 'n kulturele aktiwiteit en die bevrydende waarde daarvan. Die nar het ook besliste Bybelse konnotasies en die aspekte van verlossing en verraad is ter sprake. Die transformasieproses soos voorgestel in die film, is voltooi as die kind weer praat, verbrokkelde gesinsverhoudings herstel word, en daar ' $n$ versoening tussen gesin en gemeenskap plaasvind.

\section{Inleiding}

Katinka Heyns se rolprent Paljas is met groot verwagting in 1998 uitgereik. Hierdie rolprent was Suid-Afrika se hoop vir 'n Oscar en het in November 1998 die meeste van die belangrikste toekennings van M-Net se All Africa Film Awards gewen. Die rolprent is ook as algehele wenner aangewys. Hoewel nie met die gesogte Oscar bekroon nie, het dit wel die kortlys vir die beste buitelandse film gehaal. Die film is ook met onderskrifte uitgereik sodat dit 'n breër publiek kon bereik, en het oor 'n wye front goeie resensies uitgelok. Pretorius (1998:42) som die kwaliteit van die eindproduk oorsigtelik op as hy sê:

'n Mens is glad nie skaam dat hierdie prent in die buiteland vertoon word nie: dit is subtiel, doeltreffend onderbeklemtoon en het goeie tekstuur. [...] Wat wel belangrik is, is dat Heyns op 'n manier kuns teruggebring het na die rolprent, dit verplaaslik het en 'n rolprent gemaak het wat die filmkuns ernstig opneem. Dit beteken nie dat ons hiermee 'n rolprent kry wat net oor hoë kuns gaan nie; Paljas kyk ook met insig na die lewe van gewone mense.

Die draaiboek is deur Chris Barnard geskryf. Die storie is op die oog af bedrieglik eenvoudig. Die spoorwegwerker Hendrik McDonald (Marius Weyers) woon met sy disfunksionele gesin op 'n afgeleë stasie in die Karoo. 'n Sirkustrein arriveer op die stasie en verpas sy aansluiting. Hendrik, sy vrou Katrien (Aletta Bezuidenhout) en hul dogter, Emma (Liezel van der Merwe), en seun, Willem (Larry Leyden), se lewens word in die loop van die verhaal verander weens Willem se verhouding met die verloopte sirkusnar, Manuel (Ellis Pearson). As gevolg van die nar se magiese teenwoordigheid leer Willem weer praat en sy heling lei tot die transformasie en heling in die gesin se verbrokkelde verhoudings; 'n proses wat uiteindelik ook in die breë gemeenskap neerslag vind. 
Paljas is die ou Slamse woord vir toorgoed. 'n Paljas is 'n sakkie met toorgoedjies wat saamgedra is vir helende krag. Wat minder bekend is, is dat dit ook die ou Boerewoord is vir 'n nar, en ook vir die bonatuurlike. Die HAT (1994) gee die volgende inskrywing:

'Toor' 1. lets wonderbaarliks verrig deur geheimsinnige handeling; op bonatuurlike wyse iets teennatuurliks tot stand bring. 2. Deur towery in 'n sekere toestand, op 'n sekere plek bring; toertjies, kunsies uitvoer. 3 . Wonderlike effekte bereik.

Ingebed in die titel word die nar dus reeds as persoon, sowel as die handeling van toor in die vooruitsig gestel. Toor as handeling kan egter positiewe én negatiewe assosiasies hê: "White and black magic, art and the devil's art get confused" (Viljoen, H., 1998:17).

As vertrekpunte vir hierdie betoog geld die volgende kwessies:

- Daar word van die veronderstelling uitgegaan dat die sentrale problematiek onderliggend aan die verhaal, naamlik 'n stagnering in interpersoonlike verhoudings en 'n gepaardgaande identiteitsproblematiek, onder andere toegeskryf kan word aan die ruimtelike isolasie waarin die karakters hulle bevind. Daar sal dus eerstens aandag geskenk word aan die wyse waarop ruimte in die film funksioneer.

- Tweedens word die wyse waarop transformering in die verhaal bewerkstellig word, in oënskou geneem.

- In die derde plek word die rol van die nar in die transformeringsproses ondersoek.

\section{Die rol van ruimte in Paljas}

Vanweë die feit dat die ruimtelike problematiek aanleidend is tot die sentrale problematiek in die film, word enkele aspekte rondom die funksionering van ruimte in die film vervolgens uitgelig. 'n Ondersoek na die rol wat ruimte in die rolprent speel, kan 'n groot omvang aanneem; daarom sal daar selektief en illustratief met enkele teoretiese begrippe en toepassings omgegaan word.

Van Driel en Westermann (1991:51-117) se filmanalise bied nuttige omskrywings van aspekte wat spesifiek aan die film gekoppel kan word. Hulle uitgangspunt is die vraag wat gebeur wanneer 'n filmkyker in 'n bioskoopsaal 'n film probeer begryp. Enersyds is "begryp" vir hulle die konstruksie van 'n verhaal (tyd, ruimte, samehang). Andersyds skenk hulle aandag aan die filmiese vormgewing, en die wyse waarop 'n film na die werklikheid verwys deur die weergawe van woord en klank. 
'n Film is altyd die registrasie van die werklikheid, maar met dié voorbehoud dat die ruwe materiaal van die werklikheid deur middel van seleksie en verbandlegging 'n nagenoeg geslote betekenissisteem laat ontstaan. Binne dié sisteem kan deur die samehang tussen elemente 'n nuwe betekenis ontstaan wat slegs geld binne die medium film, of selfs net in die bepaalde film. Hierdie visuele betekeniselemente is onder andere ruimte, kader (raam), personasies/karakters en tyd.

Van Driel en Westermann (1991) maak 'n onderskeid tussen a-filmies, pro-filmies en ante-filmies. Die a-filmiese verwys na die deel van die werklikheid wat ook voortbestaan na die einde van die film. Die profilmiese verwys na elemente wat spesiaal vir die opname gekonstrueer is. Saam vorm hulle die ante-filmiese: die waarneembare (film) werklikheid soos deur die kamera en mikrofoon geregistreer. Die ruimte in die film word begrens deur die beeldkader/raam, en skuif as 't ware tussen die uiterstes van die a-filmiese (die letterlike plek) en die pro-filmiese (die dekor, die opelug of die studio) in.

\subsection{Drie aspekte van ruimte}

By die beskrywing van die ruimte in 'n film onderskei hulle die volgende drie aspekte, naamlik die topografiese ruimte, die relasionele ruimte en die simboliese ruimte.

- Die topografiese ruimte is die ruimtelike omgewing wat noodwendig aanwesig is vir die voltrekking van die gebeure. As iets gebeur, veronderstel dit immers 'n ruimte. Ruimte kan óf a-filmies (landskap) óf pro-filmies (dekor) wees en dit is altyd ikonies.

- Die term relasionele ruimte dui op die letterlike betekenis van die topografiese ruimte wat 'n bykomende verwysende of indeksale funksie kry. Dit geskied deur middel van die seleksie en kombinasie van ruimtelike elemente wat met mekaar en met die personasies wat binne dié ruimte funksioneer, in verband gebring kan word. Die benoeming van die verhouding tussen ruimtelike elemente en die personasies kan deur middel van opposisionele pare (kontraste of parallelle) geskied. Die ruimtelike duiding van "aarde" vs. "lug" kan byvoorbeeld die indeksale betekenis van "begrens" en "onbegrens" kry. Hierdie opvatting sluit aan by Lotman (1977:218) se stelling dat die mens die werklikheid hoofsaaklik in ruimtelike terme probeer verstaan. Hy wys voorts óók daarop dat die mens gestalte gee aan kulturele modelle deur ruimtelike hiërargiese en binêre opposisies, soos byvoorbeeld "hoog" vs. "laag", toe te pas op nieruimtelike verskynsels soos "goed" vs. "sleg". 
- By simboliese ruimte verwys 'n aspek van die ruimte na 'n betekenis gebaseer op 'n afspraak. Dit kan slegs geld vir die bepaalde film of meer algemeen funksioneer, en het dikwels 'n beslissende invloed op die verhaalstruktuur.

Giannetti (soos aangehaal deur Van Nierop, 1998:123) maak die volgende stelling: "Settings are not merely backdrops for the action, but symbolic extentions of the theme and characterisation. Settings can convey an immense amount of information or location." Van Nierop (1998:123-130) bespreek vervolgens die rol van die regisseur se keuse ten opsigte van ruimte (setting) onder die volgende hoofde:

- ruimte as 'n verlenging van die karakter se gemoedstemming;

- as direkte invloed op sosiale gedrag;

- as weerspieëling van 'n karakter;

- as nabootsing van die werklikheid;

- as gelaai met simboliese betekenis;

- as refleksie van 'n periode;

- as estetiese of dekoratiewe faktor.

Sowel Van Driel en Westermann as Van Nierop se onderskeidings en opvattings van ruimte maak dit duidelik dat die ruimte waarin die film afspeel (soos in die literêre werk), bykomende konnotasies of betekenisdimensies het. Hierdie addisionele konnotasies of betekenisnuanses kom tot stand as gevolg van die wyse waarop die ruimte verfilm is, en dus deur die toeskouer waargeneem word, asook as gevolg van die manier waarop ruimte deur die karakters in die verhaal beleef word.

\subsection{Topografiese ruimte in Paljas}

Die topografiese ruimte waarin die gebeure in Paljas afspeel, is grotendeels a-filmies: Paljas is naamlik in 1996 by Toorwater in die Klein Karoo verfilm. Dié bar, uitgestrekte Karoolandskap word 'n dwingende gegewe en ook 'n betekenisvolle bydraende faktor in die loop van die verhaal, met ander woorde dit word ook 'n relasionele ruimte. Die gepubliseerde draaiboek (Barnard, 1998:4) gee die volgende beskrywing: "Die landskap is die Karoo. 'n Uitgestrekte, eenselwige, eensame omgewing met gannabos, skaap en koringlande. En dansende lugspieëlings." Die McDonald-gesin bevind hulle op 'n verlate stasietjie binne dié uitgestrekte landskap. Lotman (1977:218) se opvatting oor 'n kulturele model, sowel as Van Driel en Westermann (1991:84) se opvatting van die relasionele ruimte as indeksaal, is pasklaar van toepassing. Die uit- 
gestrekte, eenselwige omgewing verwys indeksaal na geestelike isolasie en 'n gemarginaliseerde bestaan. Selfs die lugspieëlings kan dui op die gesinslede se verlore/vergete drome, terwyl die plattelandse bestaan 'n sekere agterlikheid suggereer. Die geslote ruimte van die stasiekantoor verwys na die geestelike afsondering en gevangenskap van Hendrik McDonald binne gesinsverband, terwyl die geslote ruimte van die kombuis dieselfde raamwerk is vir Katrien se bestaan. Willem ervaar die afgesonderde buitekamer waar die nar versteek word as 'n veilige, geborge ruimte van ontvlugting. Die kerk wat binne 'n Christelike konteks 'n liefdevolle, gemeenskaplike ruimte moet wees, verwys egter juis na die liefdelose, apatiese en selfs haatdraende instelling van die gemeenskap/kerkgangers.

\subsection{Geografiese en persoonlike isolasie}

Die gesin se geografiese isolasie word van die staanspoor af beeldmatig beklemtoon. In die openingskote van die film kom 'n trein in die donker aangestoom en gaan in die nag verby. Die toonaard van afsondering en isolasie kry reeds sodoende beslag. Vanuit 'n hoë-hoekskoot kan vervolgens gesien word hoe Katrien en Willem na die bus stap en Hendrik op sy eie na sy verlate stasiekantoortjie. As die kamera inzoem op die naam Toorwater is dit van agter 'n doringdraad - 'n indeksale teken dus van die geografiese én geestelike gevangenskap waarin die gesin hul bevind. Die impak daarvan op elkeen se persoonlike belewing kom ook aan die bod. Op simboliese wyse dui die treine wat nooit stop nie op die groter wêreld wat by hulle verbygaan. Hierdie ruimtelike isolasie het persoonlike isolasie tot gevolg, en uiteindelik 'n stagnasie in interpersoonlike verhoudings. Dit veroorsaak ongelukkigheid en angs by elk van die onderskeie gesinslede. Daar is dus sprake van identiteitsproblematiek op persoonlike én sosiale vlak, wat direk aan die ruimtelike opset gekoppel kan word.

Die persoonlike identiteitsproblematiek lei binne gesinsverband tot verbrokkelde, disfunksionele verhoudings. Hendrik en Katrien se huweliksverhouding het geleidelik verbrokkel. Hough (1998:27) maak die stelling dat Katrien die barometer is van wat met die gesin gebeur. Haar dun laprokke spreek van armoede en is simbolies van die geestelike bankrotskap wat heers. Die egpaar se eensame afsondering in die landskap word ook geestelike eensaamheid, en hulle wonder hoe hulle by dié punt gekom het. Katrien beskuldig en verwyt Hendrik sy onbegrip:

Jy's vyf en veertig en wat het jy? Niks. Net mooi niks. Jy's vyf en veertig en jy pas 'n stasietjie op waarvan almal al vergeet het. Jy's grootmeneer en jy't baie te sê ... (42) 
Hulle dogter Emma speel nie meer klavier nie en raak ook al meer in haarself gekeer. Sy ontwyk mense en weier toenadering. Die impak van die gesin se afsondering en gebrek aan kommunikasie word geaksentueer deur die klem wat op praat as handeling gelê word. Dit is die beduidendste by die jongste seun, Willem. Hy het twee jaar vantevore opgehou praat. Hy kán praat, maar wil nie. Oudokter diagnoseer dit as 'n angstoestand of bloot net ongelukkigheid met die lewe. Daar is talle eksplisiete verwysings na praat in die loop van die verhaal: onvermoë om te práát (dus werklik te kommunikeer); die dwingende behoefte om te praat, maar veral ook Hendrik se vermoë om die verkeerde ding op die verkeerde tyd te sê.

\subsection{Ruimtelike en sosiale isolasie}

Die identiteitsproblematiek kring ook uit na die breër gemeenskap, want die gesin bevind hulle op die rand van ander se bestaan. Die gesin is gemarginaliseerd ten opsigte van hulle gemeenskap as gevolg van hul ruimtelike isolasie, sosiale klas, andersoortigheid en armoede, maar ook as gevolg van wanbegrip by die Ander. Hulle word vals beskinder en verstoot op grond van verkeerde aannames. Du Toit (1998:6) verwoord hierdie aspek soos volg:

... maar dit gaan ook oor die keersy van buitestanderskap - oor die samelewing se instellings (soos die kerk, in dié geval) wat buitestanders dikwels buite hou en soms van mense wat binne is, buitestanders maak. Ons beleef mense se onverdraagsaamheid en die konsekwensies daarvan. Ons sien hoedat vrees en agterdog liefde kan verdring en medemenslikheid kan doodmaak.

Ook Greig (1998:14) maak insiggewende stellings oor die redes vir die gesin se sosiale isolasie:

It comes with certain colonial overtones of the locals' insecurity and sense of inferiority faced with the foreign visitor as well as the flipside - that is, the locals' need to demonstrate, often violently, their downat-earth superiority over effete foreigners.

Binne gesinsverband kan Hendrik McDonald, ten spyte van sy patriargale status, as gemarginaliseerd beskou word. Sy verhouding met sy vrou, sowel as met sy kinders, is glad nie na wense nie. Hy lewe egter in 'n leuen en maak asof niks in sy gesin verkeerd is nie. Saans luister hy na plate van Joseph Schmidt en Tino Rossi; musiek oor ver en vreemde plekke. Dit simboliseer sy onderliggende hunkering na geluk vir homself én vir sy gesin soos inderdaad ook blyk uit sy mymering: 
Ek wonder darem hoe is al daardie plekke wat hulle so van praat. [...] Jy weet, London en al die plekke. Of is dit nou byvoorbeeld mooier as die Klein Karoo en so. Of is die mense daardie kant nou beter of slimmer of ryker of wat? Klink my hulle is gelukkiger. (12)

\subsection{Naamgewing en simboliese ruimte}

Naas die letterlike en figuurlike fokus op die geografiese afsondering van die gesin is die rol van naamgewing 'n belangrike ruimtelike gegewe in terme van simboliese ruimte. Die gesin verhuis met verloop van tyd van die een geografiese ruimte na die volgende. Die eiename van dié ruimtes is duidelike voorbeelde van die wyse waarop naamgewing ruimte kan laai met bykomende simboliese betekenis. Die name is ironiese verwysings na die verbrokkelde huweliksverhouding, sowel as die gesin se toenemende isolasie van mekaar én die buitewêreld, soos blyk uit Katrien se woorde:

Op Touwsrivier twintig jaar terug het almal gesê jy gaan stasiemeester wees voor jy dertig is. Toe kom Emma. Toe Lydenburg. Toe Soekmekaar. Toe kom Willem. Toe begin als verkeerd loop. Toe Twyfelfontein. Elke stasie 'n bietjie kleiner, bietjie valer, bietjie verder van als af. Nou sit ons hier. Kyk hoe lyk als, Hendrik. Kyk hoe lyk ons ... (46)

Hein Viljoen (1998:16) wys tereg daarop dat die gesin se gemarginaliseerde status grootliks vrywillig en deur Hendrik se eie toedoen is. Hy het naamlik as gevolg van ongekontroleerde agterdog en jaloesie telkens na 'n kleiner stasie verhuis om sy vrou van gewaande buite-egtelike verhoudings te weerhou.

Tans bevind die gesin hulle op Toorwater en ook hierdie eienaam het simboliese waarde, want ingebed in dié naam skuil die moontlikheid van 'n vrugbare ommekeer en groei. Daar is reeds daarop gewys dat "toor" onder andere ook beteken om iets wonderbaarliks te verrig, of om wonderlike effekte te bereik. Volgens Cirlot (1983:365) dui die simboliese betekenis van water onder andere op kreatiwiteit, hergeboorte en regenerasie. Al hierdie moontlikhede word in die loop van die film volvoer. In die laaste skote word gewys hoe Willem teen die windpomp opklim terwyl die grootmense feesvier. Hierdeur word beeldmatig gesê dat die ruimte ook deur die voorafgaande gebeure getransformeer is. Isolasie en ingeperke visie is opgehef om plek te maak vir 'n blik op die groter wêreld daar buite. Die windpomp is terselfdertyd 'n indeksale teken van vrugbare water wat vir menslike gebruik na die oppervlak gebring word; op simboliese vlak dui dit op die moontlikheid van nuwe geestelike groei. 


\section{Die rol van die nar in die transformasieproses}

Die transformasieproses in die verhaal word aangestig deur die nar wat van die sirkus wegvlug en op die verlate stasie agterbly. Daar is veral twee aspekte met betrekking tot die nar en sy rol in die gebeure wat van belang is. In die eerste plek kan die nar se narrespel, dit wil sê die onverwagte verdwyning en onnutsige herverskynings as pikareske vertonings bestempel word. In die tweede plek het die nar in hierdie narratief besliste Bybelse konnotasies. Die nosie van verlossing en verraad is veral ter sake.

\subsection{Die nar as pikaro}

Salomi Louw (1984:8) wys daarop dat die nar (en sy verwante met ander benaminge) blykbaar sy oorsprong in die ou Griekse komedies van 500400 v.C. het. Die doel van die nar in die drama is dan tweërlei van aard: om te vermaak, en om die waarheid op onaanvegbare wyse te laat blyk.

Die pikareske roman of skelmroman (Sp.: novele picaresca) is 'n subgenre wat in die 16de eeu in Spanje ontstaan het. Van Gorp (1978:15) beskryf die pikaro as "een marginale figuur, een outsider ... helemaal geen held ... veeleer een antiheld". Volgens Bisschoff (1992:382) gaan dit in die pikareske roman veral om sosiale protes, want die pikaro leef in 'n gemeenskap wat hom stief behandel. Van Gorp (1978:172) wys voorts op die spanning tussen die individu (die pikaro as subjek) en die maatskappy, asook die konfrontasie van die pikaro met die samelewing. Hy verduidelik voorts:

Het hoeft ons dan ook niet te verwonderen dat vele neo-picareske anti-helden uitgebeeld worden in outsidersfiguren als het kind ..., de kunstenaar of clown ... en de beatnik ...; zij belichamen een aantal geestelijke waarden die in een moderne maatschappij weinig of geen kans meer krijgen.

\subsubsection{Die pikaro as buitestander}

Die nar in Paljas is inderdaad (soos ook die McDonald-gesin) 'n maatskaplike randfiguur, 'n ontsetelde outsider op 'n onbelangrike sylyn, maar is op paradoksale wyse terselfdertyd die spilfiguur waarom die belangrikste gebeure in die fiksionele wêreld draai. Hy speel 'n beslissende rol in die proses om die kind se ingekeerde wêreld te transformeer, maar hy is ook die een wat die konfrontasie met die gemeenskap op die spits dryf. Van Schalkwyk, Du Plooy en Carstens (2002:208) wys daarop dat die paradoks ook 'n tussenruimte, 'n limen of drempel, ' $n$ oorgangsruimte of halfwegstasie van transformasie en individuasie verteenwoordig. Hierdie stelling kan inderdaad ook op die nar as 
personasie in Paljas van toepassing gemaak word. Die nar word deur Willem in die buitekamer versteek; 'n marginale ruimte op die rand van die gemarginaliseerde ruimte van die gesin. Die buitekamer dien as 'n beskutte oorgangsruimte vir die kind. Dít is die plek waar hulle onbevange aan kreatiewe handelinge soos musiek maak, teken en speel kan uiting gee. Op paradoksale wyse word dit egter terselfdertyd 'n profane ruimte as die gemeenskap toeslaan en die buitekamer as 'n plek van duiwelsaanbidding verklaar.

\subsubsection{Die pikaro en rolspel: verskillende maskers}

Naas die pikaro se buitestanderskap is rolspel 'n sentrale gegewe wat op die pikaro van toepassing is. Wicks (1974:245) maak die volgende stelling ten opsigte van die pikaro as protagonis:

... a pragmatic, unprincipled, resilient, solitary figure who just manages to survive in his chaotic landscape, but who, in the ups and downs, can also put that world very much on the defensive. The picaro is a protean figure who can not only serve many masters but play different roles, and his essential characteristic is his inconstancy - of life roles, of self-identity - his own personality flux in the face of an inconstant world.

Die rolspel van die pikaro kan eerstens geïnterpreteer word as die uitspeel van 'n rol op die verhoog van die lewe in die algemeen. Wicks (1974:247) kan weer eens ter bevestiging aangehaal word: "Picaresque life is a constant change of masks on the world-as-stage." Geklee in die narrepak en verskuil agter die narremasker word dié spel 'n vorm van bemagtiging en 'n wyse van oorlewing vir die sosiaal gemarginaliseerde. Ingebed in die rolspel is egter ook 'n bevrydende aspek. Wicks (1974: 246) verklaar:

The picaro is freed, usually by necessity, from the confines of ordinary social life, and he roams the landscape; this is paralleled on the narrative plane by his desire to 'free' himself from his life by turning it into art.

Reed (1987:77) wys op 'n ander faset van rolspel met betrekking tot die pikaro: "Paradoxically, donning a mask leads to an unmasking when the play is finished. Acting a role is often heuristic and leads to self-discovery."

Wanneer Willem, sowel as die toeskouer, die eerste keer kennis maak met die nar in Paljas is dit 'n verruklike, selfs magiese gesig. Die kamera fokus op die leë stuk Karoolandskap met die horison hier naby. Vanuit dié niet verskyn die kop en rug van 'n olifant. Wanneer hy halfpad oor die 
bult is, word die nar wat huppelend voor hom stap, sigbaar. Geklee in sy volle narremondering lei die nar die olifant aan 'n tou. Die olifant hou op sy beurt die tou met sy slurp vas. Hierdie kleurvolle versteuring van die eenselwige Karoolandskap speel in op die stagnante identiteite en verhoudings. Die volgende kameraskoot op die eensame, swygsame kind se gesig by die aanskoue van dié pikareske verskyning spreek boekdele. Die nar se verskyning hou nie verband met die werklikheid nie. Hy "speel" sy "lewensrol" as nar uit teen die leë Karoolandskap sonder toeskouer of doel, en hierdie magiese alleenspel bevestig waarskynlik sy persoonlike vryheid. Terselfdertyd kan die afleiding ook gemaak word dat hy juis sy persoonlike bemagting en oorlewing as outsider deur middel van dié rolspel uitleef.

Ná Willem en die nar se kennismaking is daar 'n subtiele verandering in die spelelement, want nou speel die nar nie meer sy eie lewensrol alleen nie, maar ook die rol van begeleier op die pad na transformasie en heling. Hy betree die stil wêreld van die ongelukkige kind deur middel en by wyse van spel. Die spel verkry gevolglik 'n bewustelike element. Dit word veral bevestig deur die nar se optrede, maar veral sy woorde aan die hartseer Willem na Hendrik en Katrien se rusie.

Nee-nee-nee-nee-nee-nee. Nie trane nie. Die lewe is te kort vir trane. Ons speel liewer. Speel is altyd beter as trane. Altyd. (Die nar voel in sy sakke rond en haal 'n grimeerpotlood uit. Hy verf twee groot boë bokant Willem se ö̈.) Kom. Kom ons teken iets. (Hy soek in sy broeksak en haal 'n ander kleur uit. Hy verf Willem se mond.) Kom ons teken die trane weg. Ons vee die ou Willem uit en ons teken 'n nuwe Willem. (43)

\subsection{In alle erns speel-speel}

Victor Turner (1982) skryf gesaghebbend oor die individu se oorgang van een status na die ander binne die gemeenskap. Hy volg met sy navorsing oor dié sogenaamde oorgangsrites ("rites of passage") in die spore van die Belgiese antropoloog Arnold van Gennep. Turner (1982: 24) onderskei drie fases in hierdie rites, naamlik 'n fase van skeiding ("separation"), 'n fase van oorgang of limen ("transition") en 'n fase van inlywing ("incorporation"). Hy gebruik ook die terme preliminale, liminale en postliminale. In die liminale fase is die nosie van spel en die rituele handeling veral van belang. Hierdie fases kan ook op die gebeure in Paljas van toepassing gemaak word. Aan die begin van die film bevind die gesin hulle in die preliminale fase. Die koms van die nar en die handeling van spel dui op die liminale of oorgangsfase.

Huizinga (1958:29) beskryf die essensie van spel soos volg: 
... spel is een vrijwillige handeling of bezigheid, die binnen zekere vastgestelde grenzen van tyd en plaats wordt verricht naar vrijwillig aanvaarden doch volstrekt bindenden regel, met haar doel in zich zelf, begeleid door een gevoel van spanning en vreugde, en door een besef van 'anders zijn' dan het 'gewone leven' ... Spel scheen als een der meest fundamentele geestelijke elementen van het leven te mogen worden aangemerkt.

Die belangrikste eienskap van spel is dat dit geen doel op sigself het nie. Spel het net sin solank dit gespeel word. Kazemier (1968:7) wys op 'n ander eienskap van spel, naamlik dat dit die speler tydelik na 'n ander wêreld verplaas. Die spel vervreem die speler tydelik van die realiteit. "Het gaat om die andere wereld, die zo boeiend is door zijn vele mogelijkheden en de spanning die er telkens weer ontstaat door de onzekerheid, of de mogelijkheid werklijkheid zal worden" (Kazemier, 1968:8). Die spel vind sy moontlikhede in die verkenning van die ander wêreld en die uitbuiting van die moontlikhede van die speelwêreld.

Spel is in sy synsvorm dubbelsinnig. Die afwisselende verhouding tot die speelwêreld en die reële werklikheid konstitueer 'n bestaansvorm wat "spel" genoem kan word. Hierdie dubbelsinnige wesensaard van spel manifesteer dikwels in die opposisie-pare wat die beoefening van die spel oproep en wat mekaar op markante wyse komplementeer: triomf en neerlaag, vreugde en verslaentheid/hartseer, leeglê en daadkrag, lojaliteit en afguns, lomp en rats, spel en erns, selfs lewe en dood. Vergelyk ook die paradoksale van die hanswors: dit wat nie ernstig geneem word nie, moét soms ernstig opgeneem word.

In die wêreld van die spel is daar dikwels sprake van identifikasie of 'n drang na identifikasie. Deur middel van vereenselwiging met ' $n$ ander geïdealiseerde persoonlikheid verryk die mens hom as 't ware met dié persoonlikheid en sy geïdealiseerde eienskappe. Selfs negatiewe emosies of drange kan sonder nadelige gevolge, deur middel van vereenselwiging, in die spel uitgeleef word. Kazemir wys pertinent op die sterk drang tot identifikasie by die kind en skryf dit toe aan "gevoelens van innerlijke zwakte, fantasie- en bedreigingen van het eigen lk-bestaan als drijfveren ..." (Kazemier, 1968:11).

Die wesenlike dubbelsinnige aard van die spel, sowel as die identifikasieverskynsel, manifesteer die beste in die figuur van die harlekyn of die nar wat met sy maskerpak en gepoeierde gelaat die geïdealiseerde wêreld verteenwoordig, terwyl die realiteit van die mens daaragter in werklikheid heel anders kan uitsien.

Kenmerkend van spel is die magiese aard daarvan. As gevolg van die vermoë van spel om die mens na 'n ander wêreld te verplaas, ontstaan 
'n magiese sfeer waarin die mens sy fantasieë kan uitleef en aan sy onderdrukte wense en begeertes kan uiting gee. Die mens met sy eksistensiële lewensangs en sy onvermydelike doodsangs, kan binne die magiese sfeer van die spel die Unheimliche, die angs van lewe en dood besweer.

Turner (1982:37) se opvattings oor vryheid en die idee van spel is ook relevant: "freedom to transcend social structural limitations, freedom to play ... with ideas, with fantasies, with words (...), with paint (...), and with social relationships" (Turner se kursivering).

Bogenoemde tiperende eienskappe van spel kan bykans almal herlei word na die spelelement in Paljas. Reeds met die eerste kennismaking verlei die nar die kind om saam te speel. Hy laat die kind die olifant aan die tou lei, en die kind gee by wyse van spreke sy eerste treë in die besweringsproses. Die draaiboek beskryf dit soos volg:

'n Montage van die olifant wat al agter Willempie aanstap. Eers met die nar naby hulle. Dan met die nar op die agtergrond. Daarna net Willempie en die olifant. Oor 'n bult, deur 'n land vol koringbale, deur 'n stroom water, oor 'n brug, deur 'n bos. Willempie stap al hoe regopper, al hoe meer kordaat - en die olifant waggel agterna. (23)

Hierdie montage is koderend vir die res van die gebeure in die verhaal. Die kamera beklemtoon beeldmatig die omringende landskap, sowel as die verhouding tussen die nar, die kind en die landskap, met die uiteindelike fokus op die kind binne dié landskap. Die bar, leë Karoolandskap word sodoende getransformeer tot die magiese, en die kind word op simboliese wyse binne dié magiese sfeer geplaas om op die pad van selfhandhawing te kom. Kazemier (1968:10) se stelling met betrekking tot spel in die algemeen kan hier spesifiek op Willem van toepassing gemaak word: "Door te spelen kunnen kind en volwassene hun lewensangst binden. Reeds als kind heeft de mens leren ervaren, dat het spel bevrijdend werkt, d.w.z. conflicten tot oplossing kan brengen." Op grond van sy besweringsmoontlikheid werk spel dus bevrydend.

Die identifikasie met die nar en die geïdealiseerde wêreld manifesteer op reële vlak in die kind wat in die loop van die verhaal 'n identiese narrepakkie dra, en ook sy gesiggie soos dié van die nar verf. Op hierdie wyse konstitueer hy die afwisselende verhouding tot die verbeelde speelwêreld en die reële werklikheid. Saam met die nar speel hy haashaas, laat hy 'n rooi-en-geel vlieër vlieg en waag hy sy hand aan die konsertina. Van belang is dat die kamera in hierdie montages voortdurend fokus op die verhouding van die figure met die relasionele ruimte van die omringende landskap. Die term landskap is tersaaklik. Louise 
Viljoen (1998:75) maak 'n terminologiese onderskeid ten opsigte van landskap in navolging van Schama, Coetzee en Miller. Sy wys daarop dat die term landskap die bykomende konnotasie het van 'n ruimte gelaai met estetiese waarde of ervaring, dikwels georden volgens bepaalde estetiese beginsels wat verband hou met tradisies in die skilderkuns, soos byvoorbeeld die pittoreske of die sublieme. Waar die landskap ter sprake is, val die fokus op aspekte van die natuurlike omgewing soos die geografie en die plantegroei, maar daar is desnietemin sprake van 'n historiese, politieke en kulturele dimensie. In die montages waar die kind en die nar spelend in die landskap figureer, word die klem gevolglik telkens gelê op die handeling, maar ook op die bykomende konnotasie gelaai met estetiese waarde of ervaring. Daar is dus weer eens sprake van ' $n$ relasionele ruimte wat ' $n$ indeksale funksie kry. Dit verwys naamlik na die rol wat kuns by implikasie in die film speel. Kreatiwiteit in die gesin word aanvanklik onderdruk as gevolg van ongelukkigheid. Die nar laat Willem teken en leer hom dans en musiek maak, benewens die feit dat hy hom in die wêreld van die spel inlei. In navolging van Huizinga (1958:29), soos reeds aangehaal, moet in gedagte gehou word dat spel ook 'n fundamentele geestelike aktiwiteit is. Die nar leer Willem dus die transformatiese krag wat in kreatiewe en geestelike waardes ingebed is.

Die transformasieproses in die kind word voltrek as hy eerstens spontaan leer lag en uiteindelik weer begin praat. Hierdie heling word duidelik met die nar in verband gebring, soos blyk uit die volgende woorde:

HENDRIK: Wat praat jy nou? Jy't hierdie kind se tong weer losgeknoop!

MANUEL: (verbaas) Wie - ek?

KATRIEN: Ja, jy. Jy’t die paljas op hom gesit. (85)

Dit is veelbetekenend dat Willem se eerste woord binne gesinsverband "Speel" (62) is. Hy rig 'n dwingende versoek aan Emma om weer klavier te speel. Sy reageer aanvanklik huiwerig, maar later met meer selfvertroue. Deur dié kreatiewe handeling van spel begin die helingsproses dus ook by haar.

\subsection{Die nar as verlosser}

Onderliggend aan Chris Barnard se draaiboek kan generiese tekste uitgewys word. In die eerste plek word Abraham $\mathrm{H}$. de Vries se titelverhaal van sy gelyknamige bundel, Nag van die Clown (1989) betrek. Opvallende tekens van die "onderliggende" teks skyn deur. De Vries se verhaal vertel ook van 'n verloopte clown wat hom iewers in die 
Karoo bevind nadat hy van die sirkus ontsnap het. Ook in De Vries se verhaal speel die trein 'n beslissende rol. In De Vries se bundel Skaduwees tussen skaduwees (1997), vertel hy in 'n verhaal met dieselfde titel van die bondeldraers van die Klein Karoo, daardie vreemdelinge wat in jou lewe kom en dan weer verdwyn. Een van hierdie persone is Hondewater se clown wat op 'n dag op die stasie opdaag en die stasiemeester se gebreklike, stom seuntjie leer lag en praat deur middel van speletjies en tekeninge op die buitekamer se mure. In 'n onderhoud met Elsa Krüger vertel De Vries dat hy hierdie verhaal aan 'n etenstafel vertel het, en onbewustelik so die kiem geplant het vir die latere rolprent, Paljas (Krüger, 1998:50).

In 'n artikel oor prosesse van verraad en verlosssing in die kortverhaal "Nag van die Clown" wys Etienne van Heerden op die feit dat daar aspekte van die volwasse Christus in die clown van die kortverhaal aanwesig is (Van Heerden, 1996:117). In hierdie geval is die Bybelse gegewe dus die generiese teks. Daar kan met stelligheid beweer word dat dieselfde van die nar in Paljas gesê kan word. Die naam van die nar is Manuel, 'n afkorting vir Emmanuel (God met ons); 'n naam wat ook aan Christus gekoppel is. Soos Christus as Bemiddelaar na die aarde gekom het om troos en heling te bied, kom die nar in die lewens van die McDonald-gesin en bewerkstellig hy transformasie en uiteindelike heling op geestelike vlak. As sy taak voltooi is, vertrek hy weer per trein na sy oorspronklike bestemming.

Van Heerden (1996:127) wys in sy artikel op die generiese elemente van Christus as slagoffer van verraad en sy vrywillige kruisdood, wat met nuwe of vreemde elemente oor die stramien van die Bybelse oerverhaal skuif in De Vries se verhaal. Ook in Paljas kan elemente van die Bybelse gegewe herken word wat in 'n gewysigde vorm verskyn. Die nar gee hom willens en wetens oor aan die onverdraagsame gemeenskap; 'n parallel dus ook met Christus wat homself oorgegee het om 'n kruisdood te sterf. Die nar neem 'n wilsbesluit om, geklee in sy narremondering, die erediens by te woon. Sy optrede volg ná die insident waaruit dit blyk dat die predikant en die kerk die McDonalds verstoot op grond van foutiewe aannames. Die gemeenskap, en die kerk spesifiek, word dus geteken as rigied, en uit hul optrede blyk dit hoe hul afwykende interpretasie van wat in die Bybel opgeteken is, die godsdiens korrupteer. Soos in die Christus-verhaal gaan die boodskap van liefde en medemenslikheid by hulle verby. Hulle beskou die nar as boos en gevaarlik en beskuldig hom vals van duiwelsaanbidding. Hy moet daarom as sondebok boet. Op hierdie wyse word Manuel, soos Christus én soos die clown in De Vries se verhaal, slagoffer van verraad. 
Die nar word die kerk uitgejaag en word in sy weerloosheid die prooi van jagters: die gemeenskap maak letterlik met gewere jag op hom en verwond hom. Omdat hy self die slagoffer van geestelike én fisiese pyn is, kan hy verlossing bied. Die McDonald-gesin, ook randfigure soos die mense wat Christus omring het, versorg hom en in die proses ontwikkel hulle 'n nuwe bewussyn van medemenslikheid, menswaardigheid en eiewaarde. Terwyl Hendrik McDonald by die gewonde nar sit, maak hy die volgende stelling (woorde wat ook iets van Bart Nel se bevestiging van die eie identiteit eggo):

HENDRIK: Ek is Hendrik McDonald. En ek mág ek wees. En jy mag Emma wees. En Ma en Willem en almal. Nollie Kemp is Nollie Kemp en klaar. Ons is ons met al ons skete en al. (Hy kyk skielik vir Willem.) Of wat sê jy, Willem?

WILLEM: Manuel het niemand iets gedoen nie. (80)

Hendrik se woorde is 'n (her)bevestiging van menswaardighed en eiewaarde, dus 'n (h)erkennig van persoonlike identiteit. Hein Viljoen (1998: 17) gee 'n raak opsomming: "To be human is to realise your own strangeness and existence; your own alterity and identity." Vanaf hierdie punt is die weg gebaan vir die bevestiging van die gesin se identiteit op sosiale vlak binne die groter gemeenskap.

Die nar se rol is egter uitgespeel en daarom is dit gemotiveerd dat hy die gesin verlaat om terug te keer na die wêreld vanwaar hy in die eerste plek gekom het. "Dis seker maar waar - die storie van once a clown, always a fool. Ek mis die ou groot tent. Ek weet nie hoekom nie" (84). Die Bybelse gegewe van Christus wat die tydelike (aardse) verlaat en sy volgelinge agterlaat om sy boodskap van versoening en naasteliefde uit te leef, word dus hier ook in 'n nuwe gedaante gehul.

Aan die einde van die film is daar 'n versoening tussen die gesin en die gemeenskap. Dit is veelbetekenend dat die huis (en by implikasie die stasietjie, sowel as die afgesonderde omliggende landskap) die ruimte is waar versoening plaasvind en stagnasie finaal opgehef word. Dit beteken dat ook die ruimte waarin die karakters hulle bevind, deur die voorafgaande gebeure getransformeer is. Die derde fase waarvan vroeër in die betoog melding gemaak is, naamlik die postliminale fase, word nou betree. Die gesin, sowel as die individuele lede, is nou in staat om as getransformeerde persone weer by die alledaagse lewe in te skakel op grond van hulle nuwe sosiale identiteit. 


\section{Slot}

In hierdie artikel is vasgestel dat die ruimtelike opset waarbinne die verhaal afspeel, wel aanleidend is tot die sentrale problematiek van interpersoonlike stagnasie en afsondering. Ruimte verkry dus 'n bykomende betekenisdimensie. Die karakters, sowel as die ruimte, word op magiese wyse getransformeer deur die pikareske verskyning van die nar. Transformering geskied deur wat Turner (1982) noem "the human seriousness of play".

\section{Bibliografie}

Barnard, C. 1998. Paljas; die storie van Klara Viljee: die filmdraaiboeke. Kaapstad : Tafelberg.

Bisschoff, A. 1992. Pikareske roman. In: Cloete, T.T. (red.) Literêre terme en teorieë. Pretoria : HAUM-Literêr. p.382.

Cirlot, J.E. 1983. A dictionary of symbols. London : Routledge \& Kegan.

De Vries, Abraham H. 1989. Nag van die Clown. Kaapstad/Pretoria : Human \& Rousseau.

De Vries, Abraham H. 1997. Skaduwees tussen skaduwees. Kaapstad/Pretoria : Human \& Rousseau.

Du Toit, D. 1998. "Paljas" bly 'n mens by. Die Kerkbode,160(2):6.

Greig, R. 1998. "Paljas" turns vices of South African films into assets. The Sunday Independent. 14, Jan. 25.

HAT, 1994

kyk Odendal, F.F. 1994. HAT. Verklarende handwoordeboek van die Afrikaanse taal.

Hough, B. 1998. Brose, "siek" gesin in Katinka se Paljas genees deur nar. Rapport, 28(4):27.

Huizinga, J. 1958. Homo Ludens. Proeve eener bepaling van het spel-element der cultuur. Haarlem : Tjeenk Willink.

Kazemier, G. 1968. Nijhoff, de speelse. In: Kazemier, G. et al. Het spel in de literatuur. 's-Gravenhage : Servire/Wassenaar. p.6-31.

Krüger, E. 1998. 'n Paljas op Paljas. De Kat. 50-55, Jan.

Louw, S. 1984. Die nar en sy voorkoms in Bartho Smit se dramas. Tydskrif vir Letterkunde, 22(2):8-11, Mei.

Lotman, J.M. 1977. The structure of the artistic text. Ann Arbor : University of Michigan.

Odendal, F.F. 1994. HAT. Verklarende handwoordeboek van die Afrikaanse taal. Johannesburg: Perskor.

Pretorius, W. 1998. Paljas laat ons weer hoop. Insig: 42, Feb.

Reed, H.R. 1987. Theatricality in the picaresque of Cervantes. Cervantes: Bulletin of the Cervantes Society of America, 7(2):71-84.

Turner, V. 1982. From ritual to theatre. The human seriousness of play. New York : Performing Arts Journal Publications.

Van Driel, H. \& Westermann, M. 1991. Het begrijpen van een speelfilm. In: Bosma, P. (red.) Filmkunde: een inleiding. Nijmegen : SUN. p. 51-118.

Van Gorp, H. 1978. Inleiding tot de picareske verhaalkunst of de wederwaardigheden van een anti-genre. Groningen : Wolters-Noordhoff. 
Van Heerden, E. 1996. Prosesse van verraad en verlossing: "Nag van die Clown" as parodie van die Kers- en kruisigingsnarratiewe. Stilet, 8(1):116-139.

Van Nierop, L. 1998. Seeing sense. Pretoria : Van Schaik.

Van Schalkwyk, P., Du Plooy, H. \& Carstens, W.A.M. 2002. Karolina Ferreira (1993) van Lettie Viljoen en Vincent van Gogh se "Die Nagkafee" (1888): 'n ruimtelikkoherente lesing. Literator, 23(2):199-221.

Viljoen, H. 1998. Marginalia on marginality. AlterNation, 5(2):10-22.

Viljoen, L. 1998. Plek, landskap en die postkolonialisme in twee Afrikaanse romans. Stilet, 10:(1):73-92.

Wicks, U. 1974. The nature of picaresque narrative: A modal approach. Publications of the Modern Language Association, 89:240-249.

\section{Kernbegrippe:}

nar

Paljas

ruimte in film

spel; die kenmerke van

\section{Key concepts:}

clown

Paljas

playing; the characteristics of

space in film 